\title{
First attempt to assess the viability of bluefin tuna spawning events in offshore cages located in an a priori favourable larval habitat
}

\author{
PATRICIA REGLERO ${ }^{1}$, ROSA BALBÍN ${ }^{1}$, AURELIO ORTEGA ${ }^{2}$, \\ DIEGO ALVAREZ-BERASTEGUI ${ }^{3}$, ANA GORDOA ${ }^{4}$, ASVIN P. TORRES ${ }^{1}$, \\ VICENÇ MOLTÓ $^{1}$, ANANDA PASCUAL ${ }^{5}$, FERNANDO DE LA GÁNDARA ${ }^{2}$ \\ and FRANCISCO ALEMANY ${ }^{1}$ \\ ${ }^{1}$ Instituto Español de Oceanografía, Centre Oceanogràfic de les Balears, Moll de Ponent s/n, 07015 Palma de Mallorca, \\ Spain. E-mail: Patricia.Reglero@ba.ieo.es \\ ${ }^{2}$ Instituto Español de Oceanografía, Centro Oceanográfico de Murcia, Puerto de Mazarrón, Murcia, Spain. \\ ${ }^{3}$ SOCIB, Balearic Islands Coastal Observing and Forecasting System, Palma de Mallorca, Spain. \\ ${ }^{4}$ CEAB (CSIC), Acc. Cala St. Francesc, 14, 17300 Blanes, Spain. \\ ${ }^{5}$ IMEDEA (CSIC-UIB), C/Miquel Marquès, 21, 07190 Esporles, Spain.
}

SUMMARY: Most of the Atlantic bluefin tuna caught by the purse-seine fleet in the Mediterranean Sea are transferred alive into transport cages and towed to coastal facilities where they are fattened. This major fishery is targeting aggregations of reproductive bluefin tuna that continue spawning within the transport cages. Our study is the first attempt to assess the viability of the spawning events within transport cages placed offshore in a priori favourable locations for larval survival. The study was conducted in June 2010 in the Balearic Sea, a main spawning area for bluefin tuna in the Mediterranean. The location of two transport cages, one with wild and one with captive tuna, coincide with the situation of the chlorophyll front using satellite imagery as a proxy for the salinity front between resident surface waters and those of recent Atlantic origin. The results showed that bluefin tuna eggs were spawned almost every day within the two cages but few or no larvae were found. The expected larval densities estimated after applying mortality curves to the daily egg densities observed in the cages were higher than the sampled larval densities. The trajectories of the eggs after hatching estimated from a particle tracking model based on observed geostrophic currents and a drifter deployed adjacent to the cage suggest that larvae were likely to be caught close to the cages within the sampling dates. Spawning events in captive tuna in transport cages may hatch into larvae though they may experience higher mortality rates than expected in natural populations. The causes of the larval mortality are further discussed in the text. Such studies should be repeated in other spawning areas in the Mediterranean if spawning in cages located offshore in areas favourable a priori for larval survival is likely to be considered a management measurement to minimize the impact of purse-seine fishing on tuna.

Keywords: bluefin tuna, larvae, geostrophic currents, transport cage, Mediterranean.

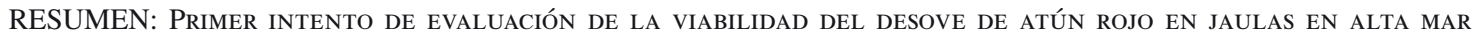
UBICADAS EN UN HÁBITAT A PRIORI FAVORABLE PARA LAS LARVAS. - La mayor parte del atún rojo atlántico capturado por la pesquería de cerco en el mar Mediterráneo es transferido vivo a jaulas de transporte y remolcado a instalaciones de engorde localizadas en la costa. Esta importante pesquería tiene como objetivo las agregaciones de reproductores de atún rojo que continúan aún su puesta en las jaulas de transporte. Nuestro estudio es el primer intento de evaluar la viabilidad del desove que tiene lugar en jaulas de transporte que están localizadas en alta mar en zonas que a priori favorecen la supervivencia larvaria. La zona de estudio está situada en el mar Balear, una de las zonas de puesta de atún rojo más importantes del Mediterráneo, en junio del 2010. La ubicación de las dos jaulas de transporte, con atún recién capturado y en cautividad respectivamente, coincide con la situación del frente de clorofila utilizando imágenes de satélite como un indicador del frente de salinidad entre aguas superficiales residentes y aquellas de origen Atlántico reciente. Los resultados muestran que hubo desove de huevos de atún rojo todos los días en las dos jaulas pero se encontraron muy pocas larvas. Las densidades de larvas que se esperaban, estimadas al aplicar curvas de mortalidad a las densidades diarias de huevos observadas en las jaulas, eran mayores que las densidades de larvas que fueron muestreadas. Las trayectorias de los huevos después de la eclosión se 
estimaron utilizando un modelo de deriva de partículas a partir de las corrientes geostróficas observadas y una boya lanzada junto a la jaula. Estas trayectorias sugieren que las larvas deberían haber sido capturadas cerca de las jaulas durante las fechas del muestreo. El desove de atún cautivo en jaulas de transporte puede dar lugar a larvas que posiblemente experimentan tasas de mortalidad más altas que las esperadas en poblaciones naturales. Las causas de la mortalidad larvaria se discuten más en detalle en el texto. Estudios como este deberían ser repetidos en otras zonas de puesta en el Mediterráneo. Especialmente, si el desove en jaulas ubicadas en alta mar en áreas a priori favorables para la supervivencia larvaria puede ser considerado una medida de gestión para minimizar el impacto de la pesquería de cerco en el atún rojo.

Palabras clave: atún rojo, larva, corriente geostrófica, jaula de transporte, Mediterráneo.

\section{INTRODUCTION}

Atlantic bluefin tuna, Thunnus thynnus, is one of the most emblematic fish species in the world because of its biological and ecological traits and the high prices it fetches in the Japanese sushi and sashimi market, where it is considered a delicacy (Safina 1993). Bluefin tuna is a large migratory fish that enters the Mediterranean Sea following the Atlantic Water that arrives through the straits of Gibraltar and converges with the resident Atlantic Water, originating the salinity-driven oceanic fronts that are the most likely areas for bluefin to spawn (Alemany et al. 2010, Reglero et al. 2012). Bluefin tuna has been exploited for thousands of years using fixed traps taking advantage of this spawning migration into the Mediterranean (Fromentin and Powers 2005). During the second half of the twentieth century new fishing techniques, such as long-liners and purse-seiners, started to be used to capture Atlantic bluefin. These fisheries mainly target schools concentrated in the spawning areas of the Mediterranean, such as the Balearic Sea and the central Mediterranean. This is the largest fleet targeting Atlantic bluefin tuna (Ottolenghi 2008).

In recent years, a new marketing system based on nearshore fattening cages has arisen. The adult bluefin tuna captured by purse-seiners are kept alive for fattening. After being caught, the fish are transported from the fishing grounds, towed at very low speeds in cages to nearshore cages where they stay until their slaughter and sale. This system of industrial farming has shown rapid development and expansion throughout the Mediterranean, with a very high economic impact (Ottolenghi 2008). Farming of Atlantic bluefin tuna is now conducted in 11 Mediterranean countries, with around 58 tuna farms and at least 51000 tonnes of farming capacity (De Stefano and Van Der Heijden 2007). These farms receive up to $99 \%$ of the catch of the purse-seine fleet and hence a great number of mature tuna are transported every year from the spawning areas to the coast (Ottolenghi 2008, Mylonas et al. 2010). Some successful spawning induction experiments carried out in captive tuna in nearshore cages initiated wide research programmes on the development of rearing techniques in the laboratory to produce fingerlings using fertilized eggs from spawning in nearshore cages (Mylonas et al. 2007; De Metrio et al. 2010). Natural spawning activity has recently been reported during the transportation of adults from fishing grounds to the nearshore cages (Gordoa et al. 2009) and also in nearshore cages out of the usual spawning sites (Mylonas et al. 2010, De la Gándara et al. 2011).
Other research has dealt with the feasibility of offshore cages for bluefin tuna aquaculture, a little-explored aspect (OATP 2007). Offshore fattening cages can improve survival and reduce parasitic infestation of adult southern tuna compared with nearshore cages, but there are still strong uncertainties related to the optimal sites for placing the cages (Kirchoff et al. 2011).

The development of the new farming system, which optimizes the commercialization and economic profit of this resource, further increased market demand for this valuable species. As a result, fishing pressure has grown in the last few years, producing a pronounced negative trend in the eastern stock of Atlantic bluefin tuna (Anon 2009, MacKenzie et al. 2009). Concern about the sustainability of this bluefin tuna stock forced the International Convention for the Conservation of Atlantic Tunas to propose a strict recovery plan, strengthening the protection measures (ICCAT 2010). This plan incorporates biological knowledge in the development of new management options to keep/increase the tuna biomass (ICCAT 2010). This management could include the possibility of maintaining the tuna transport cages in the preferential larval habitat while the captive tuna continue spawning, instead of transporting them immediately to the fattening facilities where the probability of survival for the offspring is uncertain.

Knowledge of the viability of tuna spawning events in the cages is still very poor. Hatching rates in captive tuna induced to spawn can vary from $30 \%$ to $80 \%$ in Malta (De Metrio et al. 2010), with an average hatching rate of 58\% (Selfdott 2012). In natural spawning events in captive tuna a range of $30 \%$ to $85 \%$ has been reported depending on the temperature (Selfdott 2009). After release, the survival rate in the natural environment of the larvae hatched from eggs fertilized inside the cages when located nearshore in the farms or offshore in the transport cages is totally unknown. To evaluate the impact on the stock dynamics of the offspring, and hence to consider it seriously from the management point of view, it is crucial to elucidate the viability of the eggs to the larval stage and also the survival probability of these larvae under different environmental scenarios.

The present study focuses on the fate of larvae produced from bluefin tuna spawners placed in transport cages located offshore in the Balearic Sea, one of the major spawning sites of the eastern stock of this species (Duclerc et al. 1973, Rodriguez-Roda and Dicenta 1981, Alemany et al. 2010). These cages were located in the main areas for bluefin tuna spawning in the Balearic Sea, which are most likely distinguished 
by their mesoscale hydrographic features (Alemany et al. 2010, Reglero et al. 2012). Specifically, we aim to assess the viability of the spawning events within two transport cages located offshore in terms of offspring survival measured as larval density. Because of the precise knowledge on the spatial origin of the eggs, which is usually a difficult issue for large pelagic fish, we could estimate forward tracking by advecting the recently hatched larvae in the direction of the geostrophic currents.

\section{MATERIALS AND METHODS}

\section{Field sampling}

This study was conducted in parallel with the annual spawning monitoring survey that has been performed since 2008 (Gordoa et al. 2009, Gordoa in prep.) aboard transport cages. In the 2010 spawning season two transport cages (50 m diameter, $30 \mathrm{~m}$ depth) were monitored, the first containing adult bluefin tuna caught by the purse-seine fleet at the beginning of the fishing season (cage $\mathrm{W}$, wild tuna) and the second carrying captive adult bluefin caught in previous years transferred from the Balfegó Group's fattening facilities located off L'Ametlla de Mar, NE Spain (cage C, captive tuna). Both cages were transported to the same spawning region in the Balearic Sea (Fig. 1). Surface plankton samples were collected daily between 2:00 and 4:00 AM on 16-21 June using bongo sampling gear of $60 \mathrm{~cm}$ diameter fitted with nets with a 330- $\mu$ mesh size attached to the rear of the cage; the samples were preserved for counting and validation (detailed description in Gordoa et al. 2009). Egg fertilization was confirmed by hatching experiments (Gordoa in prep.). During this period the cages were towed around a fixed point at the cruising speed of tuna transport cages, 0.69 knots.

The cages were placed coinciding with the location of the salinity front between resident surface waters and those of recent Atlantic origin (Reglero et al. 2012), as was observed from the satellite imagery. Chlorophyll $a$ concentrations (Fig. 2) were used as a proxy to locate the salinity-driven ocean front at the south of the sampling area since Chlorophyll $a$ fronts are very often related to the vertical velocities associated with ocean fronts (Landry et al. 2012). Chlorophyll $a$ concentrations were obtained from MODIS Aqua (or Moderate Resolution Imaging Spectro-radiometer aboard the Aqua satellite) mapped products, with 8-day and 4-km resolution (Feldman and McClain 2012, OceanColor 2011).

On-board the purse-seine boat TIO GEL SEGON (Balfegó tuna SL) three blocks of stations (Fig. 1) were sampled. The first one, sampled on 18 and 19 June, consisted of 19 stations placed on the nodes of a regular grid of $5 \times 5 \mathrm{nmi}(1 \mathrm{nmi}=1852 \mathrm{~m})$ based on previous ichthyoplankton cruises targeting bluefin tuna (Alemany et al. 2010), defined around the two cages. Plankton hauls were conducted using a sampling gear of $60 \mathrm{~cm}$ diameter (Bongo-60) equipped with 200 and

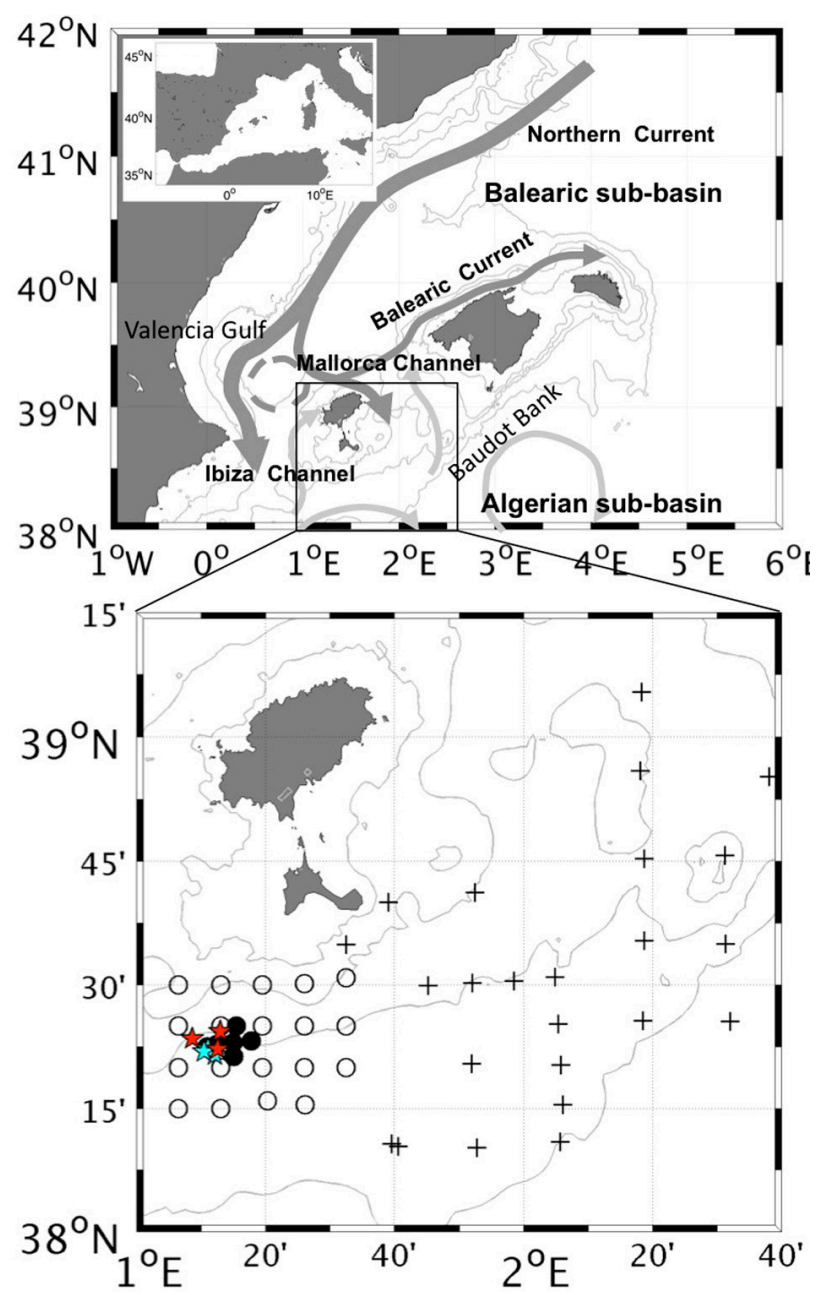

FIG. 1. - Study area and sampling stations. (Top) The Balearic Islands and the main hydrographic features characterizing the regional circulation. The Mallorca and Ibiza channels are indicated. The Northern and Balearic currents are shown as dark grey arrows and the Algerian gyres are indicated as light grey arrows. (Bottom) Sampling area with the three blocks of stations designed in the sampling strategy. Circles indicate the first block of stations, stars indicate the second block of stations and crosses the third block of stations (see description in the text). Thin, light grey lines denote isobaths in both figures $(100,500,1000$ and $2000 \mathrm{~m})$. The arrow indicates the location of the cages.

$330 \mu \mathrm{m}$ mesh size by means of oblique tows from the surface down to $20 \mathrm{~m}$. The second sampling, conducted on 20-21 June, consisted of a block of stations sampled with a WP2 equipped with a 500- $\mu$ m mesh size, towed obliquely between $20 \mathrm{~m}$ depth and the surface, whose position was defined ad hoc during the survey, taking as a reference the drift trajectory of a Lagrangian buoy. The Lagrangian buoy was deployed during the early morning on 19 June, equipped with a drogue so it was drifting at 8-15 m depth. The position of the buoy was recorded every 10 minutes during the next 2 days. Finally, a third group of stations was sampled on 22-23 June using also the WP2. This group was located over transects crossing the front. A total of 49 stations were sampled during day and night. Immediately after raising of the net, the col- 
lectors were cleaned and the samples quickly revised to detect the presence of bluefin larvae, and then preserved in $4 \%$ seawater-buffered formalin.

Once in the laboratory, zooplankton samples from both the 330- $\mu$ mesh replicate of the Bongo- 60 and the $500-\mu$ mesh of the WP2 were analysed under a stereoscopic microscope, sorting and picking up the ichthyoplankton fraction. The fish eggs were counted and the fish larvae were identified to species level. The number of eggs and larvae caught at each station was standardized to individuals per $100 \mathrm{~m}^{3}$. Bluefin larvae were measured in standard length from the tip of the jaw to the extreme of the urostyle using a stereomicroscope. Shrinkage due to preservation in formalin was corrected and length distributions converted to age from expressions obtained from laboratory experiments (see below).

\section{Hydrography}

Conductivity, temperature and pressure data were recorded at all stations, by means of Sbe 25 CTD at a sampling rate of $8 \mathrm{~Hz}$ and lowered at less than $1 \mathrm{~m} \mathrm{~s}^{-1}$. CTDs in most cases reached a depth of $350 \mathrm{~m}$, although at some selected stations they reached $650 \mathrm{~m}$ to allow for dynamic studies. All seawater parameters (salinity, $S$, potential temperature, $\theta$, and potential density anomaly, $\left.\sigma_{\theta}\right)$ and vertical profiles were processed using Sea-Bird Electronics Data Processing. Data at each station were processed at their original sampling frequency and reduced to a 1-m vertical resolution for analysis. Dynamic height at different isobaric surfaces was calculated by vertical integration of the specific volume anomaly from $350 \mathrm{~m}$ depth, which was chosen as the level of no motion (Pinot et al. 1995).

Salinity, temperature and dynamic height distributions were interpolated onto a uniform grid of $4 \mathrm{nmi}$ $\mathrm{x} 4 \mathrm{nmi}$ by using minimum error variance methods (Bretherton et al. 1976) with a correlation length of 18 nmi and a maximum allowed rms error for the interpolated field of $20 \%$. This correlation length comprised the correlation deduced from data correlation statistics plus an anti-aliasing filter. The correlation deduced from data correlation statistics specifies how far away the observed information influences the values determined over the model grid and does not depend on the way a variable is sampled but on the size of the dominant mesoescale structures (Gomis et al. 2001). Typical mesoscale structures in the study area range from 50 to $150 \mathrm{~km}$ (Millot et al. 2005). The anti-aliasing filter avoids the bias due to the smaller unmeasured scales (between 2 times the sampling length when fields are directly measured and 4 times the sampling length when high-order derived variables are considered (Pascual et al. 2004)). The geostrophic currents were estimated by first differencing the interpolated dynamic height field using finite differences.

The geostrophic currents at $15 \mathrm{~m}$ depth used to evaluate an order of magnitude of the distance that a passive drifter would be advected in a given time (which could emulate the larvae displacement) were estimated by first differencing the dynamic height field interpolated into a regular grid of $1 \times 1 \mathrm{nmi}$. The position of a virtual particle drifting on this current is calculated using a second order Runge-Kutta or midpoint method (Press et al. 2007). Diffusion and wind effects were not considered and the velocity fields are assumed to be constant during the integration time.

Sensitivity tests on the reference level of no motion and the correlation length were done to assure the robustness of the calculated geostrophic currents. Geostrophic currents were calculated for three different cases: with the standard reference level of no motion at $350 \mathrm{~m}$, using a reference level of no motion of $600 \mathrm{~m}$ and considering a correlation length of $8 \mathrm{nmi}$ as deduced from data correlation statistics plus an anti-aliasing filter calculated by convolving the weight functions of the interpolation scheme with a normal error filter, as described in Pedder (1993). The three possible drift paths of one particle released close to the initial Lagrangian buoy position and left to travel alone during 10 days did not separate tracks by more than $7 \mathrm{~km}$.

Surface water masses can be characterized after Lopez-Jurado et al. (2008), with the resident AW having a salinity of $37.50<\mathrm{S}<38.20$ and the recent $\mathrm{AW}$ a salinity of $36.50<\mathrm{S}<37.50$. We refer to surface water masses with $\mathrm{S}=37.5$ as mixed waters.

\section{Laboratory}

\section{Shrinkage and age-length distributions}

Bluefin larvae were obtained from a spontaneous spawning of naturally fertilized eggs from captive adult tuna on 7 July 2011. This broodstock, belonging to the SELFDOTT project (EU Seventh Framework Programme, GA 212797), was logged in farming facilities at El Gorguel, Cartagena, southeast Spain, owned by Caladeros del Mediterráneo, S.L. Following the technique described in Selfdott (2012), the eggs were gathered together and transported to the Institute of Marine Oceanography in Puerto de Mazarrón. There, they were incubated in a 400-L tank at around $25^{\circ} \mathrm{C}$. About two hours after $100 \%$ of the larvae had hatched (about 30 hours after fertilization), the larvae were transferred to rearing systems. Two subsamples of the larvae hatched in the 400-L tank (around 15000 individuals each) were transferred to two 1500-L tanks at an initial temperature of $25^{\circ} \mathrm{C}$ that was slowly cooled down to favour thermal acclimatation for the larvae.

Temperatures varied from $23^{\circ} \mathrm{C}$ to $25.2^{\circ} \mathrm{C}$ in tank 1 and from $23.8^{\circ} \mathrm{C}$ to $25.2^{\circ} \mathrm{C}$ in tank 2 , with an average temperature in both tanks equal to $24.4^{\circ} \mathrm{C}$. The sea water salinity was the natural one in the area, close to 37. The experiment lasted for 24 days and the photoperiod was 14 hours light: 10 hours darkness. During photophase, light intensity was 500 lux. The larvae were fed manually with live preys supplied in excess: 
enriched rotifer (Brachionus plicatilis) between 2 and 18 days post-hatching, enriched Artemia salina instar II between 16 and 21 days post-hatching and sea bream yolk sac larvae from 22 days post-hatching onwards. In addition, cultivated microalgae (Nannochoropsis gaditana) were added twice per day until day 18 .

Every two or three days, 10 larvae were photographed alive and measured in total and standard length using an image analysis system (Leika Qwin). Once dead, the larvae were measured again after preservation in formalin to mimic cruise conditions. The expression relating standard length of live and preserved larvae (both in $\mathrm{mm}$ ) was estimated for larvae between 2 and $8 \mathrm{~mm}$ standard length:

$$
\begin{gathered}
\mathrm{SL}_{\text {alive }}=1.0058 \mathrm{SL}_{\text {formol }}+0.6902 \\
\left(\mathrm{n}=58 ; \mathrm{R}^{2}=0.95 ; \mathrm{p}<0.001\right)
\end{gathered}
$$

The relationship between the age (days post hatching) and the larval length $\left(\mathrm{SL}_{\text {alive }}\right.$ in $\mathrm{mm}$ ) was obtained from the laboratory for larvae between 0 and 24 days post-hatching and the range of standard lengths between 2 and $8 \mathrm{~mm}$. Of all different fits the best fit (highest $\mathrm{R}^{2}$, lowest $\mathrm{p}$ compared with a linear or logtransformed relationship) was an exponential curve with the equation

$$
\begin{gathered}
\mathrm{SL}=3.1247 \exp ^{0.0425 a g e} \\
\left(\mathrm{n}=163 ; \mathrm{R}^{2}=0.86 ; \mathrm{p}<0.001\right)
\end{gathered}
$$

After clearing the age up, Equation 2 was used to estimate the age-distribution from the length measurements of larvae caught in the field.

\section{Mortality rates}

Daily mortality rates were calculated using sizespecific mortality rates estimated for natural populations of bluefin tuna larvae in the area (Reglero et al. 2011). Daily length growth rates were obtained from the age-length relationship (Eq. 2). We used the observed egg densities in both cages as input densities for the day-to-day mortality estimations. We assumed that eggs hatched two days after their sampling (Gordoa et al. in prep.) and simulated two scenarios assuming $30 \%$ and $80-90 \%$ of hatching rate corresponding to the minimum and maximum rates reported in the literature for viable eggs (De Metrio et al. 2010, De la Gándara et al. 2011).

\section{RESULTS}

The hydrographical scenario was characterized by a strong salinity-driven front located southwards in the sampling grid resulting from the interaction between the input of fresh Atlantic waters entering from the south and the more saline resident Atlantic waters (Fig. $3 a)$. The location of the salinity front corresponded well with the chlorophyll $a$ front observed from the satellite

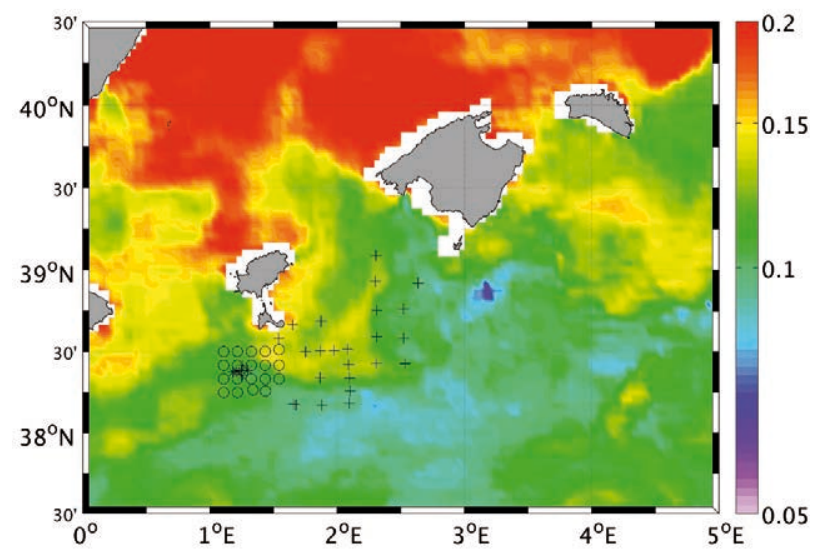

FIG. 2. - Front location. Satellite image of Chl $a$ concentration during one week around 21 June, 2010 derived from MODIS Aqua. Symbols for sampling stations as in Figure 1.

images (Fig. 2). The two cages were located at the edge of this front, at the western part, in an area being occupied at the surface almost entirely by mixed Atlantic waters (Fig. 3a). The sampling stations covered salinity ranges from 37 to 38 .

The surface mixed layer, defined as the layer where temperature and salinity are homogeneous due to solar heating and turbulence induced by wind, was between 11 and $20 \mathrm{~m}$ thickness. Sea surface temperatures varied between $20.8^{\circ} \mathrm{C}$ and $21.8^{\circ} \mathrm{C}$, with fresh Atlantic waters being at this date a bit warmer than resident Atlantic waters (Fig. 3b). Bluefin larvae were collected at $31 \%$ of the sampled stations with an average density, accounting for the positive stations, of 1.06 larvae $/ 100 \mathrm{~m}^{3}$. The highest density of bluefin larvae, 8.3 larvae $/ 100 \mathrm{~m}^{3}$, was caught at one particular station farthest east from the cage. Most of the bluefin larvae were found in water temperatures above $21.4^{\circ} \mathrm{C}$ (Fig. 3b). The trajectory of the buoy (Fig. 3c) showed the inertial oscillations, which at this latitude have a period of 19 hours and a radius that depends on the magnitude of the impulse and latitude. The net displacement after every cycle depends on the underlying current. The mean trajectory, ignoring the inertial oscillations, followed a cyclonic path in agreement with the calculated geostrophic currents at the buoy position (vectors in Fig. 3c).

The trajectory of the buoy is shown in Figure 4. The sampling period was 2.16 days. The inertial oscillations were clearly identified (Fig. 4). The oscillations were filtered out by plotting the buoy position at $0.5 \mathrm{~T}, 1.5 \mathrm{~T}$ and $2.5 \mathrm{~T}$, with $\mathrm{T}$ being the inertial oscillation period, which delivered three points that reflected the buoy trajectory without inertial oscillations (large dots in Fig. 4). Passive drifters were released at a distance of $1.5 \mathrm{nmi}$ around the Lagrangian buoy to enclose the inertial oscillation radius. The calculated drift paths of the passive drifters were nearly in agreement with the buoy trajectory after filtering the inertial oscillations. The local wind at $10 \mathrm{~m}$ above the surface re-analysed by the HIRLAM model every 12 hours (colour arrows in Fig. 4) shows that the shift in surface wind from SW at day 1 to SE at day 1.5 is 

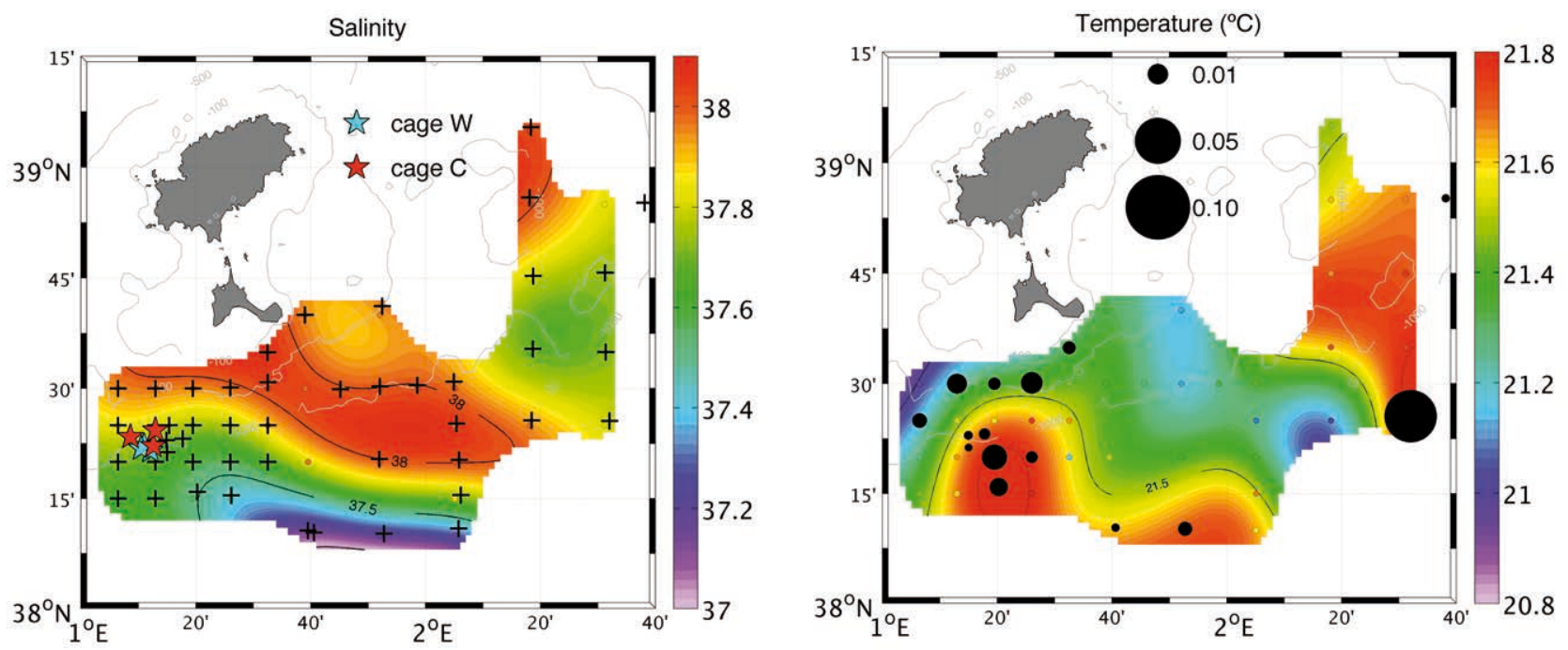

FIG. 3. - Hydrographical and biological data. (a) Biological sampling stations (crosses) and interpolated mixed-layer salinity field. The blue and the red stars indicate the position of cage W (wild) and C (captive), respectively. (b) Bluefin tuna larval densities (in ind $/ 100 \mathrm{~m}^{3}$ ) and interpolated mixed layer temperature field. (c) Buoy trajectory starting at the cage position $\left(38^{\circ} 22.5^{\prime} \mathrm{N}, 1^{\circ} 10.91^{\prime} \mathrm{W}\right)$ and interpolated dynamic height and deduced geostrophic currents.

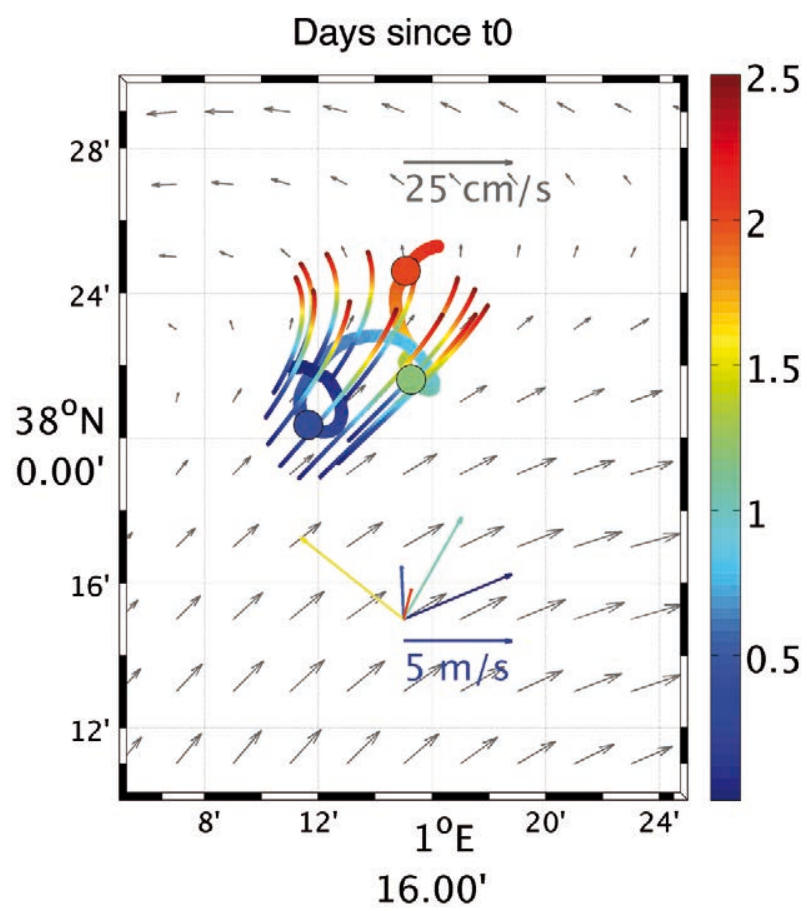

FIG. 4. - Buoy trajectory. Trajectory of the buoy indicated by the thick coloured curve. Colour bar indicates the time elapsed since the buoy was released, in days. Coloured dots indicate the position of the buoy after $0.5 \mathrm{~T}, 1.5 \mathrm{~T}$ and $2.5 \mathrm{~T}$, with $\mathrm{T}$ being the inertial oscillation period (19 hours). Thin coloured curves indicate the drift patterns of the passive drifters released over the mixed layer at a distance of $1.5 \mathrm{nmi}$ around the Lagrangian buoy. The coloured arrows at the bottom of the figure indicate local wind $10 \mathrm{~m}$ above the surface, reanalysed by the HIRLAM model, for days $0,0.5,1,1.5$ and 2. The grey arrows indicate the deduced geostrophic currents used to compute the passive drifts.

in agreement with the abrupt change of the Lagrangian buoy path at that time. This could explain the slight disagreement of the trajectory of the drifters, which ignore the wind effects, with the buoy. mean age of sampling (days)

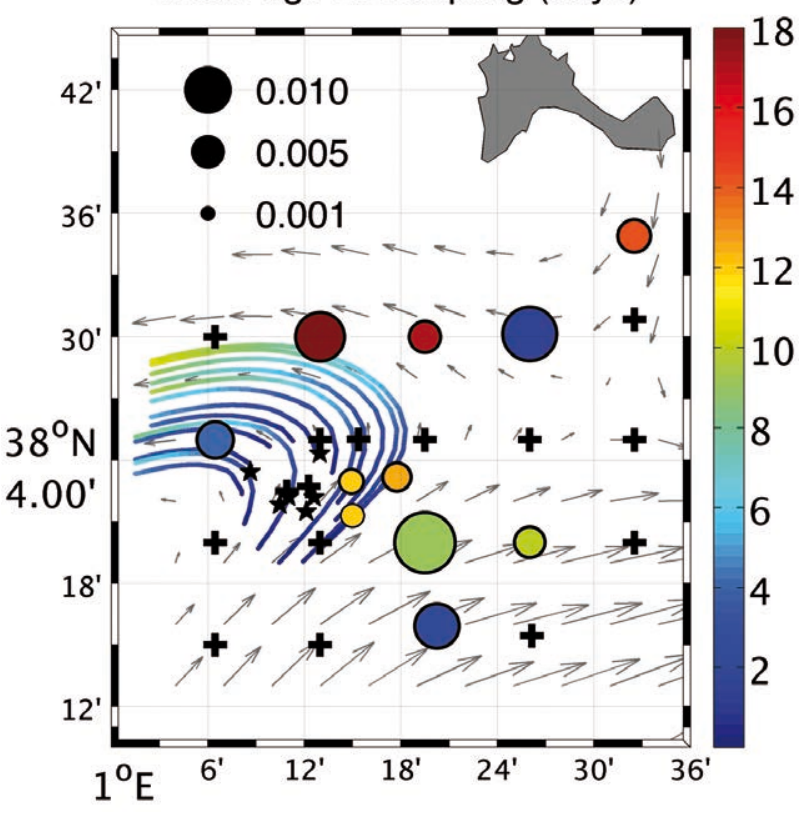

FIG. 5. - Drift trajectories and age-dependent larval spatial distributions. Crosses indicate stations sampled. Coloured dots over sampled stations indicate mean age of bluefin tuna larvae in days as indicated by the colour bar. Bluefin tuna densities (in ind $/ 100 \mathrm{~m}^{3}$ ) are indicated by the dot size. Thin coloured curves indicate the drift trajectories of ideal passive drifters released over the mixed layer at a distance of $2.5 \mathrm{nmi}$ around the initial position of the Lagrangian buoy. Colours of the curves indicate the time elapsed since they were released in days, as indicated by the colour bar. Open circles indicate the two cage positions at days 0,1 and 2. Grey arrows indicate the geostrophic currents. The black stars indicate the positions of the cages.

Tuna eggs were collected from both cages almost every day with densities varying between 2817 and 36056 eggs/100 $\mathrm{m}^{3}$ in cage $\mathrm{W}$ and between 1408 and 16901 eggs/100 $\mathrm{m}^{3}$ in cage $\mathrm{C}$ (Table 1 ). The eggs from 
TABLE 1. - Observed egg densities collected by the two cages (wild and captive). The expected egg density after applying the natural mortality (NM) curve and assuming $80 \%$ and $30 \%$ hatching success are also indicated.

\begin{tabular}{ccccc}
\hline Date & Wild & Captive & $\begin{array}{c}\text { Expected after NM, 80\% } \\
\text { hatching success }\end{array}$ & $\begin{array}{c}\text { Expected after NM, 30\% hatching } \\
\text { success }\end{array}$ \\
\hline 16 June & 11737 & 0 & & \\
17 June & 36056 & 1408 & & 570 \\
18 June & 7042 & 7512 & 1521 & 2060 \\
19 June & 2817 & 1878 & 2695 & 1506 \\
20 June & 34648 & 9390 & 1026 & 645 \\
21 June & 21127 & 16901 & 158 & 158 \\
22 June & & & & \\
\hline
\end{tabular}

both cages were fertilized and most eggs were in the first cleavage stage. The expected larval densities given the initial eggs estimated after the mortality model (Table 1) were well above the values obtained on the cruise. The age of the bluefin larvae in the area around the cages ranged from 3 days old, just hatched, to 18 days old (Fig. 5). The drift paths of the pseudo-particles released from the cage were transported out of the sampling area towards the west in 3 to 8 days (Fig. 5). Only one station at the west with larvae younger than 5 days old matched the drift pattern well, whereas the rest had larvae older than would have been expected if they had come from the observed spawning events in both cages. At most stations no bluefin tuna larvae were captured (crosses in Fig. 5).

\section{DISCUSSION}

Our study is the first to assess the viability of bluefin tuna spawning events in offshore cages located in an a priori favourable spawning habitat. Routine monitoring adjacent to the cages before and during our cruise confirmed that both recently caught and captive tuna were releasing fertilized eggs in the cages located offshore. This has been previously shown for tuna during the transport to the coast (Gordoa et al. 2009), and confirms spawning activity in captivity. Our previous knowledge of the ecology of this species in the Balearic area has allowed us to describe a priori optimal scenarios where the cage was placed regarding larval habitats. This description is based on previous information that indicates salinity fronts as the favourable habitat for the youngest tuna larvae (Reglero et al. 2012) and the relation between $\mathrm{Chl} a$ fronts and the vertical velocities associated with ocean fronts (Landry et al. 2012).

Our larval densities are in the range of the average natural bluefin larval densities usually reported for in the same area at this time of the year (Alemany et al. 2010, Torres et al. 2011) but we expected a patch of larvae to be found surrounding the cage according to the egg values and the mortality curve. The diameter of high-density patches of tuna larvae, from our experience (Alemany et al. 2010, Torres et al. 2011), is within an approximate 6-7 nmi range, which is in accordance with the results obtained by Satoh (2010) for Pacific bluefin tuna (T. orientalis) and by Davis et al. (1991) for Sourthern bluefin tuna (T. maccoyii). In our case, the cages containing the spawners, which spawned every day, were towed at a speed of 0.69 knots over a circle of less than $2 \mathrm{nmi}$. Therefore, a systematic sampling grid of $5 \times 5 \mathrm{nmi}$ should be suitable to detect the successive patches of eggs and larvae originating daily at a given point (which are expected to be distributed in patches with a range of 6-7 nmi) and suitable to capture the larvae if present.

Peaks around 100 bluefin larvae $/ 100 \mathrm{~m}^{3}$ have been reported previously in the Balearic Sea (Alemany et al. 2010), and even up to 795 larvae/100 $\mathrm{m}^{3}$ within the core of a natural population composed of 5- to 6-dayold larvae sampled in June 2011 in a nearby area (own unpublished data). Higher density values of up to 2200 larvae/100 $\mathrm{m}^{3}$ were reported in the Indian Ocean for T. maccoyi larvae (Davis et al. 1990). According to our estimations similar densities could be expected to be observed in the larval patches originating from spawning events inside the cages. However, the maximum density of bluefin larvae in this study was 8 lar$\mathrm{vae} / 100 \mathrm{~m}^{3}$ but the mean age of the larvae at this station was 4.6 days, so they were not expected to come from the cages. In fact, bluefin tuna larvae were found at only $30 \%$ of the sampled stations, with average densities of bluefin around 1 larvae $/ 100 \mathrm{~m}^{3}$, a low average larval density compared with what we expected on the basis of our mortality scenarios.

Our results show that pseudo-particles need more than 8 to 10 days to leave the dense sampling grid around the cage. Most tuna larvae are concentrated in the mixed layer (Satoh 2010, unpublished results), which during our cruise was located in the upper 20 $\mathrm{m}$. Therefore, we used geostrophic velocities at $15 \mathrm{~m}$ depth to estimate the larval trajectories. Maximum surface velocities in our study are around $15-25 \mathrm{~cm} \mathrm{~s}^{-1}$, in the range of those found in other bluefin tuna spawning grounds (Satoh 2010). At these velocities, the spatial structure of a bluefin tuna cohort is expected to be stable after fertilization, during advection and while entrained in mesoscale eddies (Satoh 2010).

We used size-specific mortality rates estimated from natural populations of bluefin tuna larvae in the Balearic Sea (Reglero et al. 2011). Though mortality coefficients have been estimated for larvae of other tuna species (e.g. Davis et al. 1991, Scott et al. 1993, Lang et al. 1994), age-dependent mortality coefficients have only been reported for Pacific bluefin tuna (Satoh et al. 2008, Satoh 2010). The differences between observed and expected larval densities based on the 
egg densities we found suggest that larvae in our study were subjected to higher mortalities than expected in other regions or tuna species.

The physiology of the species determines the temperature thresholds for larval survival. Temperature impacts on the tuna life-history traits could be affecting larval survival of eggs released from the cages. The minimum temperature for Pacific bluefin tuna spawning is between $20^{\circ} \mathrm{C}$ and $23^{\circ} \mathrm{C}$, though preferred temperatures are around $24^{\circ} \mathrm{C}$ (Sawada et al. 2005, Masuma et al. 2008). Yolk-sac larval duration is inversely related to temperature in Thunnus albacares (Margulies et al. 2007) and in general tuna larvae prefer warm temperatures (Boyce et al. 2008). June 2010 was colder than other years but temperatures ranged between $20.8^{\circ} \mathrm{C}$ and $21.8^{\circ} \mathrm{C}$, which is just above the lowest limit of the tolerance range of the tuna species. In the area, bluefin larvae have been caught at $20.5^{\circ} \mathrm{C}$ in other samplings in higher densities (Alemany et al. 2010).

We used age-length relationships from laboratory experiments at controlled temperatures to estimate the age of our larvae. Age-length relationships have been previously reported for Pacific bluefin tuna larva (Thynnus orientalis) (Miyashita et al. 2001, Sawada et al. 2005, Tanaka et al. 2008). Ours are the first data obtained in the laboratory for Atlantic bluefin tuna larvae (Thynnus thunnus). Our fit in comparison with the other laboratory and field data (Garcia et al. 2006) suggests that Thunnus thynnus have increasing growth potential with increasing temperature (Fig. 6). The growth equation from the laboratory was obtained for larvae feeding ad libitum. This may not be the case in larvae growing in the wild environment, where the risk of starvation may be high. Tuna larvae are not resistant to the lack of food and die quickly if they do not feed (Tanaka et al. 2008). Therefore, we expect shortage of food to have a strong effect on survival rates.

If the food is patchily distributed and limited around the cage, this may have caused a very high mortality risk for first-time feeding larvae (1-2 days old). Though our study area coincided well with a Chl $a$ front, this may not reflect high productivity for copepod naupliae, the first prey item most likely needed by the larvae to successfully start exogenous feeding. Therefore, improving our knowledge on the relationship between Chl $a$ and the food distribution suitable for the tuna larvae may be an important task for the future.

Bluefin exposed to stress reproduce but the reproductive output can be negatively affected, though it is reflected more in the fecundity than in the viability of the eggs (Corriero et al. 2011). In other trials, the fertilization rate of captive tunas has been reported to vary between $30 \%$ and $80 \%$ in hormone-induced spawning adults (De Metrio et al. 2010, De la Gándara et al. 2010). We used this range in the mortality estimations to address the worst-case scenario, though we observed that most eggs spawned in the cages were fertilized, so we believe that stress did not affect fertilization rates. Still, we do not know whether the survival of the

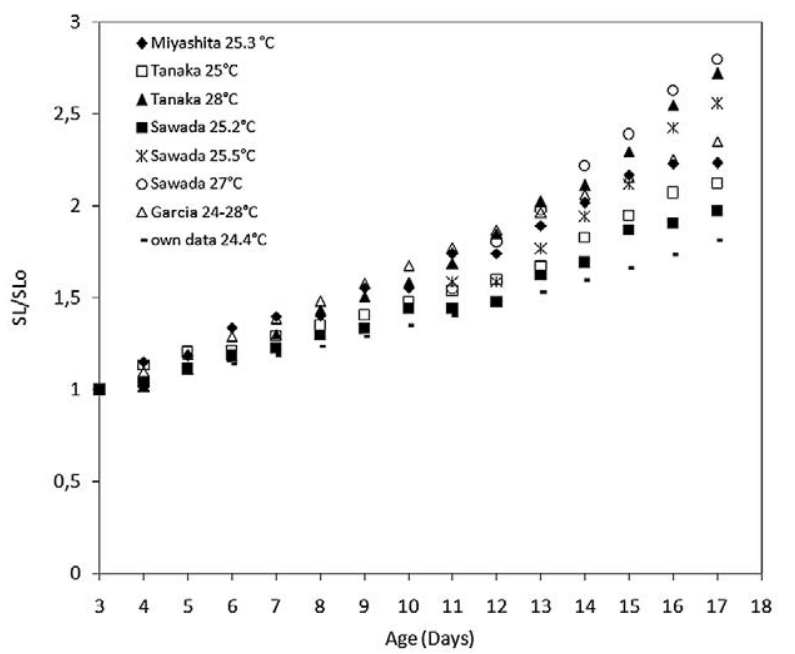

FIG. 6. - Comparison of larval growth rates. The standard length at age relative to the estimated initial length. Data from different laboratory experiments and temperatures with bluefin tuna larvae (Miyashita et al. 2001, Sawada et al. 2005, Tanaka et al. 2008), field reported data (Garcia et al. 2006) and our own experiment.

recently hatched larvae may be affected if spawning events within the cage are under stress. In general, the survival of larvae of other tuna species obtained from fertilized eggs released from spawning tuna in captivity is very low in the laboratory (Sawada et al. 2005, Masuma et al. 2006, Selfdott 2012).

Bluefin larvae hatched from the eggs produced in the cages may face high predatory pressure that can be a major source of mortality. We did not quantify predation rates on tuna larvae but we can discuss our results in the context of predation. Inter/intra-specific predation among tuna larvae from successive cohorts or spawning events has been suggested as a main process affecting larval survival (Reglero et al. 2011). Tuna larvae of ages ranging from recently hatched to 18 days old were distributed in the sampling area, suggesting that different cohorts coexisted in the same area. Larvae within that age range may still be planktivorous according to our laboratory observations. However, bluefin tuna larvae can be planktivorous in the laboratory at an older age than in natural conditions since they may be affected by excess food that is typically provided in those conditions.

The effect of another potential predator, jellyfish, on tuna eggs and larvae is unknown. Its predatory effect has been suggested from the observation of dense aggregations of jellyfish, Pelagia noctiluca, at the sea surface during the night close to the transport cage (Gordoa et al. 2009). Intense aggregations of jellyfish can cause mortality on the eggs and larvae of other fish species (Hansson et al. 2005). In the laboratory scombrid larvae successfully escaped jellyfish attacks but were still vulnerable to predation, especially at night when the fish larvae were swimming less (Masuda 2006). On our cruise we found dense aggregations of Pelagia noctiluca only at one station, the one located close to the cage, where they covered most of the sea 
surface during the night. Therefore, predation by jellyfish may have an important effect particularly on the eggs and the recently hatched larvae before they drift from the cage. Estimations of ingestion rates by jellyfish feeding on tuna eggs are needed to obtain accurate predatory mortality rates (Gordoa in prep.). Predators of bluefin larvae may also be small pelagic fishes, but Druon et al. (2011) showed little overlap of bluefin feeding and spawning potential habitat, suggesting that the impact of small pelagic fish on bluefin larvae is likely to be low.

\section{Further perspectives}

It is difficult to address all possible factors to increase the viability of the bluefin tuna spawning events in the cages. The results from our study suggest failure in larval survival though the cage was located in an a priori suitable area. Larval survival is a complex process that involves physiology, predation, feeding and dispersion, all of them related to the environmental scenarios and therefore difficult to examine. Future attempts may consider scenarios with temperatures closer to the optimal temperature for larvae $\left(24^{\circ} \mathrm{C}\right.$ rather than the $20^{\circ} \mathrm{C}$ in our study) and improve relationships between Chl $a$ and zooplankton abundance since food availability may be important for the survival of firstfeeding larvae. Our conclusions are limited since they are based on a single cruise and the monitoring of two transport cages, one containing wild adult tuna and one containing captive adult tuna. Replicates are difficult because operational costs were high and the use of the private infrastructures in this study involved a major financial investment. The Balearic Sea is one of the most important sites for bluefin tuna spawning but does not represent the entire range of conditions in which fattening activities take place (e.g. the central Mediterranean Sea). In the future some replicates for other cages in the area or at different spawning sites would be of interest to assess the generality of our results.

On the basis of our results, we cannot conclude that bluefin tuna eggs produced within the cage ensure the effectiveness of spawning events in terms of larval spillover. In summary, spawning events in captive tuna in transport cages may hatch into larvae though they may experience higher mortality rates than expected in natural populations. This finding is reflected in the low larval densities found in our study sampling around the two nets and in the relatively high number of stations where we found no larvae. It is not easy to identify places to locate offshore cages to optimize larval survival. Though we were able to predict a priori the most favourable larval habitat for bluefin tuna, the observed densities were not higher than in other areas or tuna species. New attempts to place cages offshore in potential optimal places for larval survival should consider the location of fronts and also the food abundance so that risks of starvation are minimized. Further research in additional areas in the Mediterranean may help to assess the generality of our results for other important spawning sites of bluefin tuna where transport cages could be located. Our work is a good example of how collaborative work between fishermen and researchers can lead to scientific-based knowledge that can help to evaluate the effectiveness of potential management decisions in the conservation of bluefin tuna.

\section{ACKNOWLEDGEMENTS}

We thank members of the crew and Balfegó S.L. for their support in conducting the cruise. We thank Caladeros del Mediterráneo for providing the tuna eggs for the experiments. F. Corregidor, J. Quintanilla and M. Serra, IEO technicians, assisted with sampling and B. Salamanca and J.M. Sorell assisted in the sample processing. J.L. López-Jurado, G. Vizoso and J. Tintoré provided valuable comments for the study. M. Seoka, J. Viguri, J. Prieto, R. Rodríguez, M.J. Arenas and F. Méndez helped with the experiments. Comments from anonymous referees improved the manuscript. This study was partly financed by the Baleares project (CTM 2009-07944 MAR), the Bluefin tuna project (IEO/ SOCIB agreement) and the European Community's Seventh Framework Programme (FP7/2007-2013) under grant agreement $\mathrm{n}^{\circ} 287600$-PERSEUS. A.P. Torres acknowledges pre-doctoral FPI Fellowship support from the regional government of the Balearic Islands.

\section{REFERENCES}

Alemany F., Quintanilla L., Velez-Belchi P., Garcia A., Cortes D., Rodriguez J.M., de Puelles M.L.F., Gonzalez-Pola C., LopezJurado J.L. 2010. Characterization of the spawning habitat of Atlantic bluefin tuna and related species in the Balearic Sea (western Mediterranean). Progr. Oceanogr. 86: 21-38.

Anon 2009. Report of the 2008 Atlantic bluefin tuna stock assessment session (Madrid, Spain, June 23 to July 4, 2008). Collect. Vol. Sci. Pap. ICCAT 64: 1-352.

Boyce D.G., Tittersor D.P., Worm B. 2008. Effects of temperature on global patterns of tuna and billfish richness. Mar. Ecol. Prog. Ser. 355: 267-276.

Bretherton F., Davis R., Fandry C. 1976. A technique for objective analysis and design of oceanographic experiments applied to MODE-73. Deep-Sea Res. I 23: 559-582.

Corriero A., Zupa R., Bello G., Mylonas C.C., Deflorio M., Genovese S., Basilone G., Buscaino G., Buffa G., Pousis C., De Metrio G., Santamaria N. 2011. Evidence that severe acute stress and starvation induce rapid atresia of ovarian vitellogenic follicles in Atlantic bluefin tuna, Thunnus thynnus (L.) (Osteichthyes: Scombridae). J. Fish. Dis. 34: 853-860.

Davis T.L.O., Jenkins G.P., Young J.W. 1990. Patterns of Horizontal Distribution of the Larvae of Southern Bluefin (ThunnusMaccoyii) and Other Tuna in the Indian Ocean. J. Plankton Res. 12: $1295-1314$.

Davis TLO, Lyne V, Jenkins GP. 1991. Advection, dispersion and mortality of a patch of southern bluefin tuna larvae Thunnusmaccoyii in the East-Indian Ocean. Mar. Ecol. Prog. Ser. 73: $33-45$

De la Gándara F., Ortega A., Belmonte A. and Mylonas C.C. 2011. Spontaneous spawning of Atlantic bluefin tuna Thunnus thynnus kept in captivity. In: Proceedings of the Aquaculture Europe 2011. European Aquaculture Society, Rhodes (Greece), October 18-21, pp. 249-250.

De Metrio G., Bridges C.R., Mylonas C.C., Caggiano M., Deflorio M., Santamaria N., Zupa R., Pousis C., Vassallo-Agius R., Gordin H., Corriero A. 2010. Spawning induction and large-scale 
collection of fertilized eggs in captive Atlantic bluefin tuna (Thunnus thynnus L.) and the first larval rearing efforts. J. Appl. Ichthyol. 26: 596-599.

De Stefano V., Van Der Heijden, P.G. 2007. Bluefin tuna fishing and ranching: a difficult management problem. New Medit. 6(2): 59.

Druon J.N., Fromentin J.M., Aulanier F., Heikkonen J. 2011. Potential feeding and spawning habitats of Atlantic bluefin tuna in the Mediterranean Sea. Mar. Ecol. Prog. Ser. 439: 223-240.

Duclerc J., Sacchi J., Piccinetti C., Piccinetti-Manfrin G., Dicenta A., Barrois J.-M. 1973. Nouvelles données sur la reproduction du thon rouge (Thunnus thynnus L.) et d'autres espèces de thonidés en Mediterranée. Rev. Trav. Pêches Marit. 37: 163-176.

Feldman G.C., McClain C.R. 2012.Ocean Color Web. http://oceandata.sci.gsfc.nasa.gov

Fromentin J.M., Powers J.E. 2005. Atlantic bluefin tuna: population dynamics, ecology, fisheries and management. Fish. Fish. 6: 281-306

Garcia A., Cortes D., Ramirez T., Fehri-Bedoui R., Alemany F., Rodriguez J.M., Carpena A., Álvarez J.P. 2006. First data on growth and nucleic acid and protein content of field-captured Mediterranean bluefin (Thuпnиs thynnиs) and albacore (Thunnus alalunga) tuna larvae: a comparative study. Sci. Mar. 70S2: 67-78.

Gomis D., Ruiz S., Pedder M. A. 2001. Diagnostic analysis of the $3 \mathrm{D}$ ageostrophic circulation from a multivariate spatial interpolation of CTD and ADCP data. Deep-Sea Res. I 48: 269-295

Gordoa A., Olivar M.P., Arevalo R., Viñas J., Moli B., Illas X. 2009. Determination of Atlantic bluefin tuna (Thunnus thynnus) spawning time within a transport cage in the western Mediterranean. ICES J. Mar. Sci. 66: 2205-2210.

Hansson L.J., Moeslund O., Kiørboe T., Riisgård H.U. 2005. Clearance rates of jellyfish and their potential predation impact on zooplankton and fish larvae in a neritic ecosystem (Limfjorden, Denmark). Mar. Ecol. Prog. Ser. 304: 117-131.

ICCAT. 2010. Report of the 2010 Atlantic Bluefin Tuna Stock Assessment Session. ((Madrid, Spain, 2010). http://www.iccat.es/Documents/Meetings/Docs/ 2010_BFT_ASSESS_REP_ENG.pdf).

Kirchhoff N.T., Rough K.M., Nowak B.F. 2011. Moving Cages Further Offshore: Effects on Southern Bluefin Tuna, T. maccoyii, Parasites, Health and Performance. PLOS ONE 6(8): e23705.

Landry M., Ohman M., Goericke R., Stukel M., Barbeau K., Bundy R., Kahru M. 2012. Pelagic community responses to a deepwater front in the California Current Ecosystem: overview of the A-Front study. J. Plankton Res. 34: 739-748.

Lang K.L., Grimes C.B., Shaw R.F. 1994. Variations in the age and growth of yellowfin tuna larvae, Thunnus albacares, collected about Mississippi River plume. Environ. Biol. Fish. 39: 259-270.

López-Jurado J.L., Marcos M., Monserrat S. 2008. Hydrographic conditions affecting two fishing grounds of Mallorca islands (Western Mediterranean) during the IDEA project (2003-2004). J. Mar. Syst. 71: 303-315.

MacKenzie B.R., Mosegaard H., Rosenberg A.A. 2009. Impending collapse of bluefin tuna in the northeast Atlantic and Mediterranean. Conserv. Lett. 2: 25-34.

Margulies D., Suter J.M., Hunt S.L., Olson R.J., Scholey V.P., Wexler J.B., Nakazawa A. 2007. Spawning and early development of captive yellowfin tuna (Thunnus albacares). Fish. Bull. 105: 249-265.

Masuda R. 2006. Ontogeny of anti-predator behavior in hatcheryreared jack mackerel Trachurus japonicas larvae and juveniles: patchiness formation, swimming capability, and interaction with jellyfish. Fish. Sci. 72: 1225-1235.

Masuma S., Miyashita S., Yamamoto H., Kumai H. 2008. Status of bluefin tuna farming, broodstock management, breeding and fingerling production in Japan. Rev. Fish. Sci. 16: 385-390.

Millot C., Taupier-Letage I. 2005. Circulation in the Mediterranean Sea. In: The Mediterranean Sea. Springer Berlin / Heidelberg. Volume 5 part $\mathrm{K}$ of The Handbook of Environmental Chemistry, pp. 323-334. 10.1007/b107143.

Miyashita S., Sawada Y., Okada T., Murata O., Kumai H. 2001. Morphological development and growth of laboratory-reared larval and juvenile Thunnus thynnus (Pisces: Scombridae). Fish. Bull. 99: 601-616.

Mylonas C.C., Bridges C.R., Gordin H., Belmonte Ríos A., García
A., de la Gándara F., Fauvel C., Suquet M., Medina A., Papadaki M., Heinisch G., De Metrio G., Corriero A., Vassallo-Agius R., Guzmán J.M., Mañanos E., Zohar Y. 2007. Preparation and administration of gonadotropin releasing hormone agonist (Gn$\mathrm{RHa}$ implants for the artificial control of reproductive maturation in captive-reared Atlantic bluefin tuna (Thunnus thynnus thynnus). Rev. Fish. Sci. 15: 183-210.

Mylonas C.C., Corriero A., de la Gandara F., Belmonte A. 2010. Atlantic bluefin tuna (Thunnus thynnus) farming and fattening in the Mediterranean Sea. Rev. Fish. Sci. 18: 266-280.

OceanColor. 2011. Chlorophyll operational algorithm. http://oceancolor.gsfc.nasa.gov/ANALYSIS/ocv6/.

Offshore Aquaculture Technology Platform (OATP). 2007. Evaluation of the promotion of Offshore Aquaculture through a technology platform: Summary Report from the International Workshop on Offshore Aquaculture, Dublin. Contract Number 044290. Available: http://offshoreaqua.com/articles.php. Accessed 2013.

Ottolenghi F. 2008. Capture-based aquaculture of bluefin tuna. In: Lovatelli A., Holthus P.F. (eds), Capture-based aquaculture. Global overview. FAO Fisheries Technical Paper. No. 508 Rome, FAO, pp. 169-182.

Pascual A., Gomis D., Haney R.L., Ruiz S. 2004. A quasigeostrophic analysis of a meander in the Palamós Canyon: vertical velocity, geopotential tendency, and a relocation technique. $J$. Phys. Oceanogr. 34: 2274-2287.

Pedder M. 1993. Interpolation and filtering of spatial observations using successive corrections and gaussian filters. Mon. Weather Rev. 121: 2889-2902.

Pinot J.M., Tintoré J., Gomis D. 1995. Multivariate analysis of the surface circulation in the Balearic Sea. Prog. Oceanogr. 36: 343-344.

Press, W.H., Teukolsky, S.A., Vetterling, W.T., and Flannery, B.P. 2007. Numerical recipes 3rd edition: The art of scientific computing. Cambridge University Press.

Reglero P., Urtizberea A., Torres A.P., Alemany F., Fiksen Ø. 2011. Cannibalism among size classes of larvae may be a substantial mortality component in tuna. Mar. Ecol. Prog. Ser. 433: 205-219.

Reglero P., Ciannelli L., Alvarez-Berastegui D., Balbín R., LópezJurado J.L., Alemany F. 2012. Geographically and environmentally driven spawning distributions of tuna species in the western Mediterranean Sea. Mar. Ecol. Prog. Ser. 463: 273-284

Rodriguez-Roda J., Dicenta A. 1981. Areas de puesta del atún, melva y bonito en las costas de España y Marruecos. ICCAT Collective Volume of Scientific Papers 15(2): 278-283.

Safina C. 1993. Bluefin tuna in the West Atlantic: Negligent management and the making of an endangered species. Conserv. Biol. 7(2): 229-234.

Satoh K., Tanaka Y., Wahashi M. 2008. Variations in the instantaneous mortality rate between larval patches of Pacific bluefin tuna Thunnus orientalis in the northwestern Pacific Ocean. Fish. Res. 89: 248-256.

Satoh K. 2010. Horizontal and vertical distribution of larvae of Pacific bluefin tuna Thunnus orientalis in patches entrained in mesoscale eddies. Mar. Ecol. Prog. Ser. 404: 227-240.

Sawada Y., Okada T., Miyashita S., Murata O., Kumai H. 2005. Completion of the Pacific bluefin tuna Thunnus orientalis (Temminck et Schlegel) life cycle. Aquaculture Res. 36: 413-421.

Selfdott. 2010. SELFDOTT REPORT 2009 http://hdl.handle. net/10508/356 $279 \mathrm{pp}$.

Selfdott. 2012. SELFDOTT REPORT 2010-2011 http://hdl.handle. net/10508/1118 $488 \mathrm{pp}$.

Scott G.P., Turner S.C., Grimes C.B., Richards W.J., Brothers E.B. 1993. Indices of larval bluefin tuna, Thипnиs thynnus, abundance in the Gulf of Mexico; modelling variability in growth, mortality, and gear selectivity. Bull. Mar. Sci. 53: 912-929.

Torres A.P., Reglero P., Balbín R., Urtizberea A., Alemany F. 2011. Coexistence of larvae of tuna species and other fish in the surface mixed layer in the NW Mediterranean. J. Plankton Res. 33: $1793-1812$

Scient. ed.: M.P. Olivar.

Received October 9, 2012. Accepted September 17, 2013.

Published online October 28, 2013. 